\title{
Breeding value estimation for somatic cell score in South African dairy cattle
}

\author{
B.E. Mostert ${ }^{1 \#}$, C. Banga ${ }^{1}$, E. Groeneveld ${ }^{2}$ and F.H.J. Kanfer $^{3}$ \\ ${ }^{1}$ ARC-AII, Private Bag X2, Irene, South Africa \\ ${ }^{2}$ Institute for Animal Husbandry and Animal Behaviour, FAL, Mariensee, 31535 Neustadt, Germany \\ ${ }^{3}$ Department of Statistics, University of Pretoria, Pretoria, 0002, South Africa.
}

\begin{abstract}
Two fixed regression testday models were applied for variance component estimation and prediction of breeding values for somatic cell score, using testday records of the first three lactations of South African Holstein and Jersey cows. The first model (ML-model) considered the testdays of the different lactations as different traits in a multiple-trait animal model and the second analysis (RM-model) treated later lactation records as repeated measures of the first lactation. Heritabilities from the RM-model were more in the range of literature estimates compared to that of the ML-model, i.e. $0.19 \pm 0.003$ for the Holstein breed and $0.18 \pm$ 0.003 for the Jersey breed. Rank correlations indicated that minor changes occur in the ranking of proven sires between breeding values obtained from the ML- and RM-models. Although genetic correlations between parities are not unity, the RM-model estimates more competitive variances and requires extensively less computer time to predict breeding values compared to the ML-model and are therefore recommended for breeding value estimation on a national basis.
\end{abstract}

Keywords : Fixed regressions, Holstein, Jersey, testday records, Wilmink curve

"Corresponding author. E-mail: bernice@irene.agric.za

\section{Introduction}

Mastitis is widely known as the most economically important disease in dairy cattle. It causes severe financial losses, mainly due to reduced milk yield and quality, treatment expenses and replacement costs. Improvements in management per se cannot control mastitis, as environmental organisms causing the disease cannot be eradicated. In addition, economic losses due to mastitis may increase due to the unfavourable genetic correlation between milk yield and mastitis (Emanuelson et al., 1988; Simianer et al., 1991; Mrode \& Swanson, 1996). Resistance to mastitis is therefore a major goal in dairy cattle improvement. Direct selection for this trait is difficult to carry out because, in common with other health traits, occurrence of mastitis is not routinely recorded in most dairy recording schemes and it is lowly heritable. Somatic cell counts in milk (SCC) are widely used as a means of managing udder health and are routinely recorded in most dairy recording schemes. A high positive genetic correlation has been found to exist between SCC and incidence of mastitis (Emanuelson et al., 1988; Rogers et al., 1998; Nash et al., 2000; Boichard \& Rupp, 2001; Kadarmideen \& Pryce, 2001). SCC can therefore justifiably be used as an indirect means of measuring and improving resistance to mastitis through breeding. Somatic cell count testing was initiated in the South African Milk Recording Scheme in 1995 and currently more than 80\% of the milk-recorded herds are routinely tested for SCC. Since 1996, most of the SCC data have been stored on the Integrated Registration and Genetic Information System of South Africa (INTERGIS). The aim of this study was to develop methodology and to estimate covariance matrices for the estimation of breeding values for somatic cell count on a national basis for South African Holstein and Jersey dairy cattle.

\section{Materials and Methods}

Data consisted of testday records of somatic cell count for lactations 1, 2 and 3 of Holstein and Jersey cows calving from 1995 to 2002. These records were obtained from the INTERGIS for cows participating in the South African Dairy Animal Improvement Scheme. The number of testday records that were available were 2385207 for the Holsteins and 718016 for the Jerseys. Basic edits were done on the data, deleting 7\% of the Jersey database and $21 \%$ of the Holstein database. The remaining records were used to ultimately estimate BLUP breeding values for somatic cell score.

In order to ensure a well-linked data structure for variance component estimation, the data were strictly selected according to the study of Haile-Mariam et al. (2000). Data available for variance component estimation accounted then to 111540 testday records of 32075 Holstein cows for the first parity, 115907 records of 17441 Holstein cows for the second parity and 48170 records of 7534 Holstein cows for the 
third parity, representing 728 sires, 28558 dams and 539 herds. For the Jerseys the selection ended with 87 381 testday records of 17758 cows in the first parity, 68845 records of 10054 cows in the second parity and 31203 records of 4650 cows in the third parity, representing 473 sires, 14941 dams and 261 herds.

Somatic Cell Count (1000's/ml) (SCC) was transformed to ln (SCC) for each testday to achieve normality and homogeneity of variances. The transformed values will be refered to as Somatic Cell Score (SCS). (Co)variance components were estimated using VCE4 (Groeneveld \& Garcia-Cortes, 1998) with the following genetic model:

\begin{tabular}{|c|c|c|}
\hline \multicolumn{3}{|c|}{$y_{i j k l m n}=\mu+H T D L M_{i m}+A_{j m}+P E_{j m}+S_{k m}+A C_{l m}+\operatorname{wilmink}\left(S_{k m}\right)+e i j k l m n$} \\
\hline$y_{i j k l m n}$ & $=$ & $\mathrm{n}^{\text {th }}$ test-day SCS of cow $\mathrm{j}$ in lactation $\mathrm{m}$, \\
\hline$\mu$ & $=$ & mean yield \\
\hline$H T D L M_{i m}$ & $=$ & fixed effect of herd $\mathrm{x}$ testdate $\mathrm{x}$ parity $\mathrm{x}$ number of milkings effect \\
\hline & $=$ & animal additive genetic effect \\
\hline$P E_{j m}$ & $=$ & $\begin{array}{l}\text { permanent environmental (random) effect within lactation to account for } \\
\text { common effects of environment associated with all testday records of cow } j \\
\text { in lactation m }\end{array}$ \\
\hline$S_{k m}$ & $=$ & fixed effect of calving season in lactation $\mathrm{m}$ \\
\hline $\mathrm{AC}_{\mathrm{lm}}$ & $=$ & fixed effect of ageclass in lactation m \\
\hline $\operatorname{wilmink}\left(S_{k m}\right)$ & $=$ & $\begin{array}{l}\text { Wilmink curve modelled on days in milk within season in } \\
\text { lactation } \mathrm{m} \text { (regression) }\end{array}$ \\
\hline$e_{i j k l m n}$ & $=$ & random residual error \\
\hline
\end{tabular}

Season was defined as winter (April - September) vs. summer (October - March), while the same ageclasses were allocated as in the derivation of standard lactation curves by Mostert et al. (2001). Two models were applied for analysis of these testday records. The first model (ML-model) considered the testdays of the different lactations as different traits in a multiple-trait animal model and the second analysis (RM-model) treated later lactation records as repeated measures of the first lactation, fitting the permanent environmental effect, as well as the Wilmink curve within lactation. Pedigrees were traced back for four generations, ending with 90468 animals for the Holstein and 45320 animals in the pedigree for the Jersey analyses.

BLUP breeding values were estimated using PEST (Groeneveld \& Kovac, 1990) and applying pedigrees that included genetic groups, allocated according to year of birth, selection intensity and country of birth. Rank correlations between breeding values from the ML and RM-models were done using SAS (1996).

\section{Results and Discussion}

Ratios and correlations estimated for SCS with the ML and RM-models, are listed in Table 1 for Holstein and Jersey cows. For the ML-model, a trivariate analysis was done on the Holstein data which converged after 97 iterations, giving positive definite matrices. For the Jerseys, however, matrices had to be constructed from bivariate analyses to end up with positive definiteness. Heritabilities were low for both breeds, increasing slightly with parity number. The permanent environmental effect was much higher than the heritabilities for all lactations of both breeds. Heritability estimates from the ML-model from this study are on the lower range of those reported in the literature, while the permanent environmental estimates correspond better (Reents et al., 1995a, Reents et al., 1995b, Haile-Mariam et al., 2000). The RM-model estimated heritabilities for SCS of 0.19 for the Holsteins and 0.18 for the Jerseys, while the permanent environmental effects are in the same range ( 0.19 for the Holsteins) or slightly higher ( 0.21 for the Jerseys). These estimates are more comparable with estimates used by other countries participating in INTERBULL runs to obtain Multiple Across Country Evaluation (MACE) breeding values.

Breeding values converged at 4313 iterations for the Holsteins (approximately 12 hours) and 3296 iterations (approximately 3 hours) for the Jerseys, using the RM-model. The ML-model is of course more computational demanding and was still not converged after 20000 rounds of iteration, at a stopping criterion of 0.0001 (Holsteins approximately 168 hours; Jerseys approximately 53 hours).

Proven sires rank almost the same, regardless of the model used, while $14 \%$ of the Jersey and $11 \%$ of the Holstein sires with less than 50 daughters in 10 herds, will change places in the rank between the two models. 
Table 1 Heritabilities, permanent environmental (PE) effects and correlations ( \pm s.e.) of the ML- and RMmodels (heritabilities and PE on the diagonal, correlations above the diagonal) for SCS of Holstein and Jersey cows

\begin{tabular}{|c|c|c|c|c|c|c|c|}
\hline \multicolumn{6}{|c|}{ Multiple Lactation Model } & \multicolumn{2}{|c|}{ Repeatability Model } \\
\hline \multicolumn{3}{|c|}{ Heritabilities and Correlations } & \multicolumn{3}{|c|}{ PE and Correlations } & Heritabilities & PE \\
\hline \multicolumn{6}{|c|}{ Holsteins } & \multicolumn{2}{|c|}{ Holsteins } \\
\hline Lactation 1 & Lactation 2 & Lactation 3 & Lactation 1 & Lactation 2 & Lactation 3 & & \\
\hline \multirow[t]{3}{*}{$0.05 \pm 0.004$} & $0.84 \pm 0.027$ & $0.79 \pm 0.043$ & $0.28 \pm 0.004$ & $0.38 \pm 0.009$ & $0.31 \pm 0.013$ & $0.19 \pm 0.003$ & $0.19 \pm 0.002$ \\
\hline & $0.07 \pm 0.005$ & $0.97 \pm 0.021$ & & $0.31 \pm 0.005$ & $0.53 \pm 0.011$ & & \\
\hline & & $0.07 \pm 0.008$ & & & $0.34 \pm 0.008$ & & \\
\hline \multicolumn{6}{|c|}{ Jerseys } & \multicolumn{2}{|c|}{ Jerseys } \\
\hline \multirow[t]{2}{*}{0.04} & $0.81 \pm 0.059$ & $0.75 \pm 0.083$ & 0.31 & $0.41 \pm 0.011$ & $0.24 \pm 0.018$ & & \\
\hline & 0.04 & $\begin{array}{c}1.00 \pm 0.00 \\
\mathbf{0 . 0 5}\end{array}$ & & 0.33 & $\begin{array}{c}0.50 \pm 0.013 \\
\mathbf{0 . 3 6}\end{array}$ & $0.18 \pm 0.003$ & $0.21 \pm 0.003$ \\
\hline
\end{tabular}

\section{Conclusion}

Correlations between lactations are not unity, indicating that lactations should be treated as different traits. Nevertheless the RM-model estimates more competitive variances and requires extensively less computer time in terms of national and international genetic evaluations. Although ML-models estimate more accurate breeding values, enabling breeders to weigh information from different lactations, only minor changes in the ranking of proven and less reliable sires occurred in the comparison of breeding values from the ML- and RM-models.

\section{References}

Boichard, D. \& Rupp, R., 2001. Phenotypic and genetic relationships between somatic cell counts and clinical mastitis in French Holstein cows. Interbull Bulletin 26, 66-72.

Emanuelson, U., Danell, B. \& Rupp, R., 1988. Genetic parameters for clinical mastitis, somatic cell counts and milk production estimated by multiple-trait restricted maximum likelihood. J. Dairy Sci. 71, 467476.

Groeneveld, E. \& Garcia-Cortes, A., 1998. VCE4.0, a (co)variance component package for frequentists and bayesians. Proc. $6^{\text {th }}$ World Congr. Gen. Appl. Livest. Prod. 27, 455-456.

Groeneveld, E. \& Kovac, M., 1990. A generalised computing procedure for setting up and solving mixed linear models. J. Dairy Sci. 73, 513-531.

Haile-Mariam, M., Goddard, M.E. \& Bowman, P.J., 2000. Estimates of genetic parameters for daily somatic cell count of Australian dairy cattle. J. Dairy Sci. 84, 1255-1264.

Kadarmideen, H.N. \& Pryce, J.E., 2001. Genetic and economic relationships between somatic cell count and clinical mastitis and their use in selection for mastitis resistance in dairy cattle. Anim. Sci. 73, 19-28.

Mostert, B.E., Theron, H.E. \& Kanfer, F.H.J., 2001. The effect of calving season and age at calving on production traits of South African dairy cattle. S. Afr. J. Anim. Sci. 31, 205-210.

Mrode, R.A. \& Swanson, G.J.T., 1996. Genetic and statistical properties of somatic cell count and its suitability as an indirect means of reducing the incidence of mastitis in dairy cattle. Anim. Breed. Abstr. 64, 847-857.

Nash, D.L., Rogers, G.W., Cooper, J.B., Hargrove, G.L., Keow, J.F. \& Hansen, L.B., 2000. Heritability of clinical mastitis incidence and relationships with sire transmitting abilities for somatic cell score, udder type traits, productive life and protein yield. J. Dairy Sci. 83, 2350-2360.

Reents, R., Dekkers, J.C.M. \& Schaeffer, L.R., 1995a. Genetic evaluation for somatic cell score with a testday model for multiple lactations. J. Dairy Sci. 78, 2858-2870.

Reents, R., Jamrozik, J., Schaeffer, L.R. \& Dekkers, J.C.M., 1995b. Estimation of genetic parameters for testday records of Somatic Cell Score. J. Dairy Sci., 78, 2847-2857l.

Rogers, G.W., Banos, G., Sander Nielsen, U. \& Philipsson, J., 1998. Genetic correlations among somatic cell scores, productive life and type traits from the United States and udder health measures from Denmark and Sweden. J. Dairy Sci. 81, 1445-1453.

SAS, 1996. SAS user's guide: Statistics, Release 6.12. SAS Institute Inc., Cary, North Carolina, USA.

Simianer, H., Solbu, H. \& Schaeffer, L.R., 1991. Estimated genetic correlation between disease and yield traits in dairy cattle. J. Dairy Sci. 74, 4358-4365. 